\title{
Energetic and exergetic analysis of solar photovoltaic- thermoelectric generator hybrid system
}

\author{
Parul Mertia*, Surendra Kothari and N.L. Panwar \\ Department of Renewable Energy Engineering, Maharana Pratap University of Agriculture and Technology, \\ Udaipur (Rajasthan) India \\ (Email : parulmertia@gmail.com)
}

\begin{abstract}
The objective of present study is to determine the energy and exergy performance of the developedSolar PhotovoltaicThermoelectric generator hybrid system. The experimental setup was examined under Udaipur climatic conditions $\left(24^{\circ} 35273 \mathrm{~N}\right.$; $73^{\circ} 422453 \mathrm{E}$ ). The hybrid systems convert sunlight into electric power by the PV module and then utilize the rest thermal energy by the TEG module. Based on the first law of thermodynamics, the energy analysis is used to evaluate the output performance of the hybrid system. And the output electric power of the hybrid system is calculated. Moreover, the second law of thermodynamics is applied to the exergy analysis of the hybrid system. The exergy losses caused by the irreversible process of solar radiation converted into electric power and thermal energy are evaluated. The calculation results demonstrate that exergy of system follows the incident solar radiation and most of the input exergy has been lost at output with maximum losses occur when solar radiations are converted into heat.
\end{abstract}

Key Words : Solar PV, TEG, exergy

View Point Article : Jainuddin, S.M., Seema, Suhasini, K. and Lavanya, T. (2021). Price and non-price decision making factors for groundnut production in Karnataka: An evidence from Nerlove's supply response approach. Internat. J. agric. Sci., 17 (2) : 256-261, DOI:10.15740/ HAS/IJAS/17.2/ 256-261. Copyright@2021: Hind Agri-Horticultural Society.

Article History : Received : 22.02.2021; Accepted : 14.03.2021

\footnotetext{
* Author for correspondence :
} 